\title{
Analisis Kejadian pada Sistem Pendingin Primer Reaktor Menggunakan Functional Modeling
}

\author{
Tulis Jojok Suryono*1, Sigit Santoso ${ }^{1}$, Restu Maerani ${ }^{1}$, Muhammad Subekti ${ }^{1}$ \\ ${ }^{1}$ Pusat Teknologi dan Keselamatan Reaktor Nuklir, BATAN, Gd. 80, Kawasan Puspiptek, Setu, Tangerang Selatan, Banten, \\ Indonesia
}

\begin{tabular}{l}
\hline INFORMASI ARTIKEL \\
\hline Riwayat Artikel: \\
Diterima: \\
11 November 2020 \\
Diterima dalam bentuk revisi: \\
07 Desember 2020 \\
Disetujui: \\
08 Desember 2020
\end{tabular}

Kata kunci:

Sistem pendingin primer

Manajemen penuaan

Kejadian kecelakaan

Multilevel flow modeling

Penapisan komponen

\begin{abstract}
ABSTRAK
ANALISIS KEJADIAN PADA SISTEM PENDINGIN PRIMER REAKTOR MENGGUNAKAN FUNCTIONAL MODELING. Selama waktu operasi reaktor, struktur, sistem dan komponen (SSK) reaktor, misalnya sistem pendingin primer, akan mengalami penuaan atau keusangan yang akan mempengaruhi kinerja dan operasi selamat dari reaktor tersebut. Hal ini juga berlaku pada Reaktor Serba Guna G.A. Siwabessy (RSG-GAS) yang usianya lebih dari 30 tahun. Oleh karena itu program manajemen penuaan harus dilakukan untuk mengatasi hal tersebut. Salah satu aktivitas yang dilakukan adalah dengan melakukan penapisan komponen kritis sistem pendingin primer. Penelitian ini bertujuan untuk melakukan penapisan tersebut menggunakan model multilevel flow modeling (MFM) pada sistem pendingin primer RSG-GAS. MFM adalah salah satu metode functional modeling yang mengubah sistem kompleks menjadi struktur fungsi-fungsi yang saling terhubung dengan hubungan sebab akibat. Metode yang dilakukan adalan dengan menerapkan beberapa skenario kejadian kecelakaan loss of flow accident (LOFA) yang terdapat pada Laporan Analisis Keselamatan (LAK) RSG-GAS pada model MFM tersebut. Dampak dari kejadian tersebut dapat dianalisis menggunakan aturan jalur perambatan (influence propagation). Hasil investigasi berupa komponen-komponen yang terdampak, yaitu katup isolasi, pompa primer dan alat penukar panas, dikelompokkan sebagai komponen kritis dan harus mendapat perhatian untuk penanganan lebih lanjut. Jika komponen-komponen tersebut mengalami keusangan atau kerusakan maka harus dilakukan perawatan atau penggantian sehingga kinerja reaktor dapat dipertahankan dan reaktor dapat tetap beroperasi dengan aman dan selamat.
\end{abstract}

\begin{abstract}
EVENT ANALYSIS ON THE REACTOR PRIMARY COOLING SYSTEM USING FUNCTIONAL MODELING. During the lifetime of a reactor, the reactor's structures, systems, and components (SSC), for example, the primary cooling system, will experience aging or obsolescence which will affect the performance and the safe operation of the reactor. This also applies to RSG-GAS which is more than 30 years old. Therefore, an aging management program should be conducted to overcome this problem. One of the activities is by screening the critical components of the primary cooling system. The purpose of this research is to perform the screening process by implementing accident scenarios the multilevel flow modeling (MFM) model of the primary cooling system of the RSG-GAS. MFM is a functional modeling method that transforms a complex system into function structures that are interconnected by cause-effect relations. The method used is by applying several LOFA accidents scenarios mentioned in the Safety Analysis Repot (SAR) of the RSGGAS to the MFM model. The impact of these events can be analyzed using the influence propagation rule. The results of the investigation, the affected components, such as isolation valves, primary pumps, and heat exchangers, are classified as critical components and should be considered for further treatment. If the components are obsolete or malfunctions, maintenance or replacement must be carried out so that reactor performance can be maintained and the reactor can continue to operate safely.

Keywords: sistem pendingin primer, multilevel flow modeling, manajemen penuaan, reaktor RSG-GAS, loss of flow accident (LOFA)
\end{abstract}

\section{PENDAHULUAN}

Ada beberapa faktor yang mempengaruhi keselamatan operasi reaktor nuklir yaitu faktor teknis dan faktor manusia. Faktor manusia misalnya terkait dengan kesalahan operator dalam mengoperasikan dan mengendalikan reaktor [1][2][3]. Sedangkan faktor teknis

* Penulis korespondensi

E-mail: suryono@batan.go.id menyangkut kegagalan struktur, sistem dan komponen (SSK) reaktor [4][5].

Salah satu penyebab kegagalan sistem tersebut adalah penuaan dari struktur, sistem, dan komponen (SSK) tersebut selama waktu operasi dari reaktor. Hal ini juga terjadi pada Reaktor Serba Guna GA-Siwabessyy (RSGGAS), salah satu reaktor riset milik Indonesia yang berlokasi di Puspiptek, Tangerang Selatan, Banten. Reaktor tersebut telah berusia 
lebih dari 30 tahun sehingga SSK dari RSGGAS tersebut juga akan mengalami penuaan. Oleh karena itu, agar tetap beroperasi secara selamat, dan untuk tetap mendapatkan ijin operasi dari BAPETEN sebagai badan regulasi maka harus dilakukan program manajemen penuaan. Perka BAPETEN no 8 tahun 2008 tentang Ketentuan Keselamatan Manajemen Penuaan Reaktor Nondaya [6] menyebutkan bahwa manajemen penuaan adalah "kegiatan rekayasa, operasi dan perawatan untuk mengendalikan agar penuaan pada SSK masih dalam batas yang diterima”. Fokus pada program manajemen penuaan adalah pada SSK kritis (SSK yang penting terhadap keselamatan dan rentan terhadap penuaan) melalui program inspeksi, perawatan, perbaikan dan penggantian SSK. Selain itu hal-hal yang harus diperhatikan oleh pengusaha instalasi nuklir adalah degradasi tangki reaktor, degradasi teras reaktor, keusangan sistem instrumentasi dan kendali (SIK), degradasi penukar panas, degradasi menara pendingin, degradasi struktur beton, dan ketentuan keselamatan yang baru [6].

Program manejemen penuaan juga diatur dalam Peraturan Pemerintah no 54 tahun 2012 tentang Keselamatan dan Keamanan Instalasi Nuklir [7]. Dalam peraturan tersebut disebutkan bahwa salah satu kegiatan dalam manajemen penuaan adalah deteksi penuaan yang dapat dilakukan melalui pemilihan dan kategorisasi SSK yang rentan terhadap penuaan. Dalam penelitian ini, hal ini dilakukan dengan cara menapis komponen kritis penyusun dari sistem pendingin primer RSGGAS.

Metode yang dilakukan dalam penelitian ini adalah dengan menerapkan beberapa kejadian kecelakaan yang tertera dalam Laporan Analisis Keselamatan (LAK) menggunakan model Multilevel Flow Modeling (MFM) [8] pada diagram sistem pendingin primer RSG-GAS. MFM merupakan metode yang mengubah sistem industri yang kompleks menjadi sistem yang terdiri atas fungsi dan tujuannya dan saling terhubung dengan menggunakan hubungan sebab akibat [9]. MFM telah banyak digunakan untuk analisis kecelakaan pada PLTN misalnya loss of coolant accident (LOCA) [10] dan steam generator tube rupture (SGTR) [11][12] pada PWR, serta station blackout [13] pada BWR. Kejadian kecelakaan yang digunakan pada penelitian ini adalah bagian dari loss of flow accident (LOFA) yaitu "berkurangnya aliran pendingin karena kegagalan pompa primer" dan "penutupan katup isolasi pompa primer dan alat penukar panas secara tidak sengaja”.

Tujuan dari penerapan kasus kejadian pada model MFM tersebut adalah untuk mendapatkan informasi mengenai komponenkomponen yang terdampak akibat kejadian tersebut. Kegagalan suatu komponen akan berdampak pada komponen lain dan juga sstem tersebut secara keseluruhan. Dampak dari kejadian kecelakaan tersebut, pada model MFM dari sistem pedingin primer tersebut dapat diinvestigasi menggunakan aturan propagasi dampak (influence propagation rule). Komponen-komponen terdampak hasil dari investigasi tersebut kemudian dikelompokkan ke dalam komponen-komponen kritis yang harus mendapatkan perhatian untuk deteksi penuaan sebagai bagian dari program manajemen penuaan.

\section{KEJADIAN KECELAKAAN PADA SISTEM PENDINGIN PRIMER RSG-GAS}

Sistem pendingin primer RSG-GAS berfungsi untuk menyediakan aliran pendingin dari dan ke kolam reaktor sehingga suhu dalam teras dan reflektor dapat dipertahankan pada batas operasi yang diijinkan. Sistem pendingin primer reaktor terdiri atas pompa-pompa primer dan alat penukar panas yang dihubungkan ke kolam dan teras reaktor menggunakan pipa. Gambar 1 menunjukkan diagram sederhana dari sistem pendingin primer RSG-GAS.

Seperti terlihat pada Gambar 1, sistem pendingin primer RSG-GAS mengambil panas dari teras reaktor yang dialirkan ke bawah melalui pipa yang terhubung dengan pompapompa primer. Dalam hal ini terdapat 3 pompa primer: 2 pompa beroperasi dan 1 pompa dalam keadaan standby. Melalui pompa-pompa primer tersebut, aliran panas tersebut dikirimkan ke alat penukar panas untuk diubah menjadi aliran pendingin yang akan dikirmkan kembali ke kolam reaktor. Sedangkan panasnya dibuang ke atmosfer melalui sistem pendingin sekunder. 


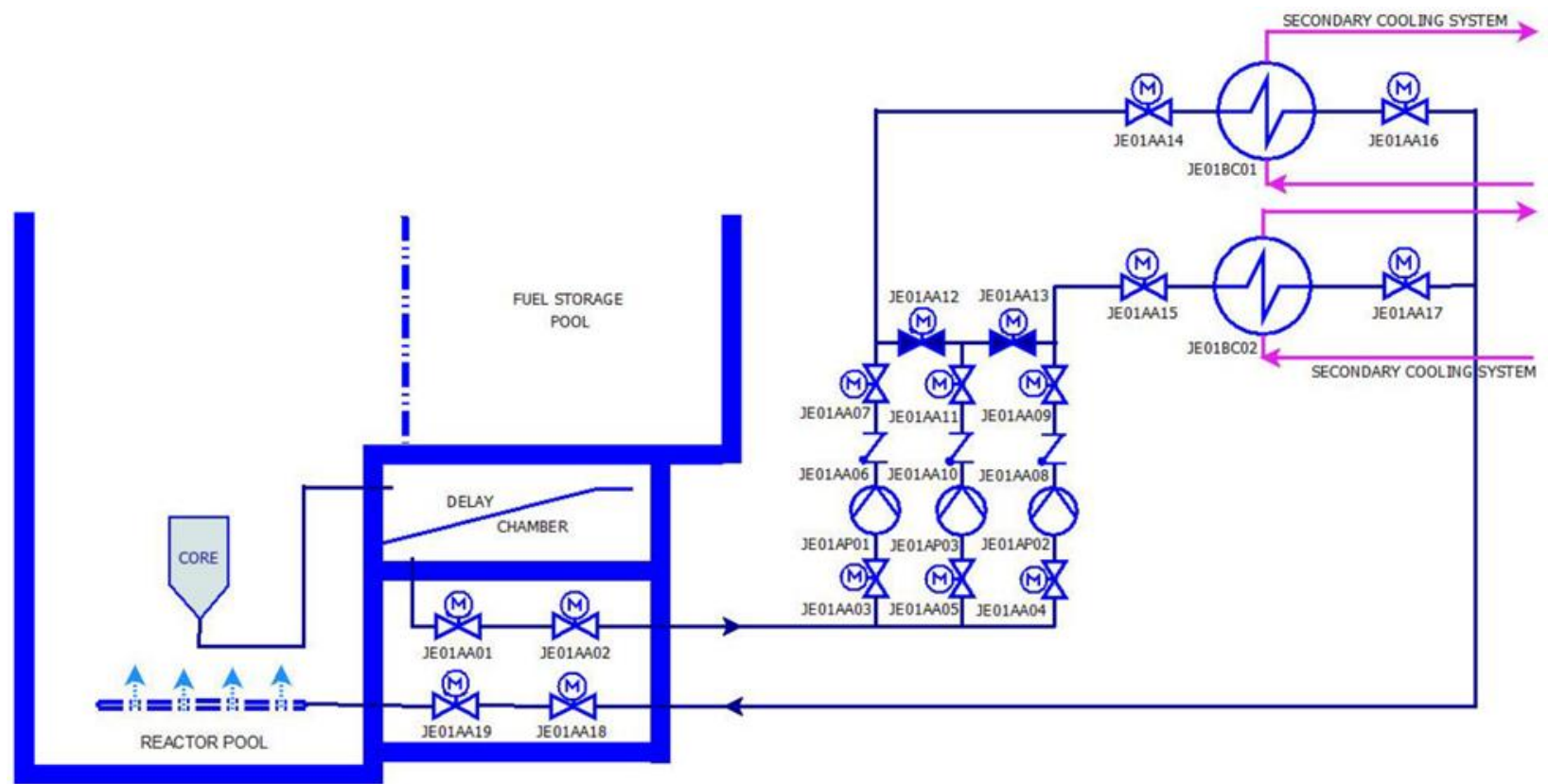

Gambar 1. Diagram sederhana dari sistem pendingin primer RSG-GAS [14].

Sesuai dengan fungsinya sebagai penyedia aliran pendingin bagi reaktor, maka kejadian kecelakaan yang mungkin terjadi pada sistem pendingin primer adalah kecelakaan akibat kehilangan pendingin (LOFA=Loss of Flow Accident), seperti yang disebutkan dalam Laporan Analisis Keselamatan RSG-GAS [15]. Ada beberapa kejadian yang terkait dengan LOFA, diantaranya adalah berkurangnya aliran pendingin karena kegagalan pompa primer, berkurangnya aliran pendingin karena kegagalan katup (penutupan katup isolasi primer secara tidak sengaja, penutupan katup isolasi primer dan alat penukar panas secara tidak sengaja, penutupan mendadak katup kupu-kupu), dan pecahnya pipa pendingin primer. Akan tetapi dalam penelitian ini hanya membahas tentang "berkurangnya aliran pendingin karena kegagalan pompa primer" dan "penutupan katup isolasi pompa primer dan alat penukar panas secara tidak sengaja”. Pemilihan kejadian ini didasarkan pada bahwa kejadiankejadian tersebut dapat merepresentasikan kinerja dari komponen utama sistem pendingin primer RSG-GAS yaitu katup, pompa primer dan alat penukar panas yang sejalan dengan tujuan investigasi untuk mendapatkan informasi komponen kritis yang berguna dalam program penapisan SSK.

\section{DESKRIPSI TENTANG FUNCTIONAL MODELING}

Functional modeling adalah metode untuk memodelkan sistem berdasarkan tujuan dan cara untuk mencapai tujuan tersebut. Salah satu metode yang digunakan adalah multilevel flow modeling (MFM). MFM adalah functional modeling yang dikembangkan oleh Lind [8] [16]. MFM model terdiri atas struktur aliran (flow structure) massa atau energi yang berisi beberapa fungsi aliran seperti terlihat pada Gambar 2.

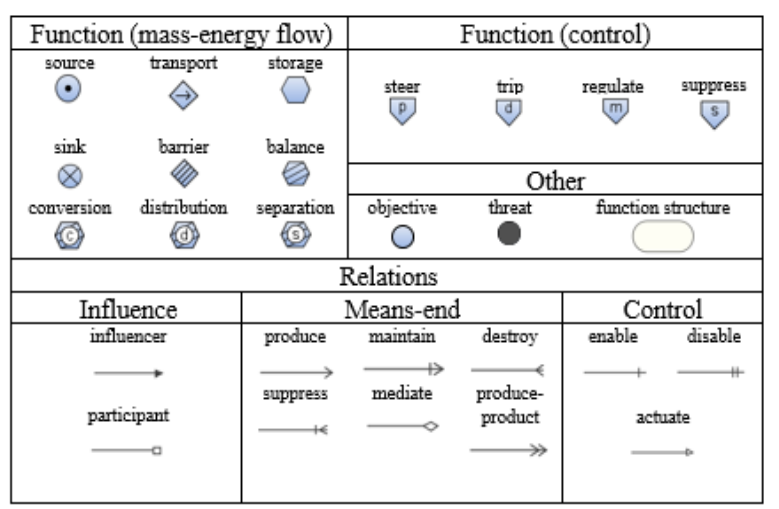

Gambar 2. Simbol MFM.

Dari Gambar 2 terlihat bahwa functions $(\mathrm{so}=$ source, tra=transport, $\mathrm{sto}=$ storage, $\mathrm{dsb})$ merupakan fungsi-fungsi penyusun struktur aliran, sedangkan control digunakan untuk Menyusun fungsi kontrol. Relations digunakan 
untuk menghubungkan antar fungsi (influence) dan antar struktur aliran (means-end). Gambar 3 menunjukkan contoh model MFM pada tangki penampung air. Dalam hal ini pompa dimodelkan dengan fungsi transport (tra1) karena mengalirkan air dari sumber ke tangki (sto1). Sedangkan tra2 memodelkan keran air yang akan mengalirkan air dari tangki.

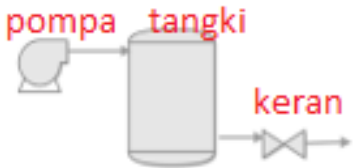

a

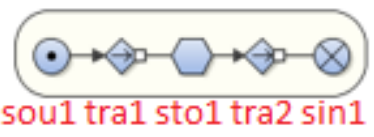

$\mathrm{b}$
Gambar 3. Model MFM dari tangki air.

MFM merupakan metode analisis kualitatif yang dapat digunakan untuk analisis sebab akibat secara cepat dan tepat dan berguna bagi sistem yang sulit untuk dianalisis secara kuantitatif. MFM selain berguna untuk memodelkan suatu sistem, juga dapat digunakan untuk menganalisis sistem tersebut, misalnya terkait dengan keandalan sistem [17], diagnostik kesalahan [18], sistem bantu operator [19], dan hubungan sebab akibat dari suatu kejadian [20]. MFM telah banyak digunakan untuk analisis pada instalasi kompleks seperti instalasi kimia [21], sistem tenaga listrik [22] dan PLTN tipe BWR [13], PWR [23] [11] [24] dan fast breeder reactor [25].

Metode MFM dapat divalidasi melalui beberapa cara diantaranya seperti yang dijelaskan dalam [26], yaitu merepresentasikan sistem menggunakan functional modeling sesuai dengan tujuan pemodelan, melakukan eksperimen validasi untuk tiap struktur fungsi secara iterative, dan memasukkan perubahan input ke dalam sistem yang sebenarnya dan mendapatkan outputnya untuk memvalidasi model fungsi tersebut. Literatur [27] menyebutkan bahwa kausalitas dari MFM dapat divalidasi menggunakan analisis kausalitas sistem, pengujian kausalitas MFM, perbandingan hasil, dan revisi model. Sedangkan Nielsen dkk dalam [28] menyebutkan bahwa kinerja MFM untuk diagnostik kesalahan dapat divalidasi dengan membandingkan dengan metode diagnostik kesalahan yang lain.

MFM menggunakan status fungsi dan tujuan untuk keperluan analisis seperti terlihat pada Tabel 1. Dari Tabel 1 terlihat bahwa untuk fungsi transport terdapat beberapa status yang dapat terjadi pada fungsi itu yaitu normal, aliran tinggi, aliran rendah, dan tidak ada aliran.

Tabel 1. Status fungsi MFM [11]

\begin{tabular}{|c|c|}
\hline Simbol & Status \\
\hline source & $\begin{array}{l}\text { Normal, potensi aliran output tinggi, } \\
\text { potensi aliran output rendah, potensi } \\
\text { tidak ada aliran output }\end{array}$ \\
\hline $\operatorname{sink}$ & $\begin{array}{l}\text { Normal, aliran input tinggi, aliran input } \\
\text { rendah, tidak ada aliran input }\end{array}$ \\
\hline transport & $\begin{array}{l}\text { Normal, aliran tinggi, aliran rendah, } \\
\text { tidak ada aliran }\end{array}$ \\
\hline storage & $\begin{array}{l}\text { Normal, volume tinggi, volume rendah,, } \\
\text { tidak ada volume }\end{array}$ \\
\hline barrier & Normal, bocor \\
\hline balance & $\begin{array}{l}\text { Normal (seimbang), tidak seimbang } \\
\text { (terisi atau bocor) }\end{array}$ \\
\hline objective & True (tinggi), true (rendah), false \\
\hline
\end{tabular}

Perubahan status fungsi MFM menunjukkan adanya kejadian pada fungsi tersebut. Sebagai contoh, untuk kasus fungsi transport yang mewakili pompa, jika kondisi awalnya adalah "normal" dan kemudian berubah menjadi "tidak ada aliran" maka dapat dikatakan bahwa fungsi transport (pompa) tersebut mengalami kegagalan fungsi (misalnya mati karena kehilangan catu daya listrik atau mengalami kerusakan komponen). Untuk melakukan analisis sebab akibat dari perubahan suatu fungsi dalam model MFM, maka digunakan aturan propagasi dampak (influence propagation rule) seperti terlihat pada Gambar 4. Dari Gambar 4 terlihat bahwa perubahan status pada suatu fungsi (lingkaran merah) akan berpengaruh pada komponen lain pada struktur aliran yang sama (anak panah berwarna merah) dan juga pada tujuan serta fungsi-fungsi pada struktur aliran lainnya (anak panah berwarna biru). Sebagai contoh, struktur aliran efs2 menggambarkan aliran energi listrik pada suatu pompa, sehingga tujuan dari sistem ini obj1 adalah menghidupkan pompa. Struktur aliran mfs2 adalah aliran air dalam suatu sistem yang dialirkan oleh pompa tersebut dan terhubung dengan tujuan sistem yaitu menyediakan aliran air ke dalam sistem. Pada kondisi awal, status masing-masing fungsi dalam struktur aliran tersebut (menggunakan nilai status fungsi MFM dalam Tabel 1) adalah "normal". Jika suatu saat pompa mengalami kegagalan catu daya listrik atau tidak ada sumber arus listrik (sou2 berubah dari "normal" menjadi "potensi tidak ada aliran output") maka fungsi lain dalam 
strukur aliran yang sama juga akan mengalami perubahan status (tra3 dari "normal" menjadi "tidak ada aliran", sin2 dari "normal" menjadi "tidak ada aliran input”). Perubahan ini juga akan mengakibatkan tujuan sistem obj1 tidak tercapai, dan sebagai akibatnya fungsi tra1 dalam mfs1 yang merepresentasikan pompa akan gagal berfungsi dan tidak dapat mengalirkan air ke sistem (tra1 dari "normal" menjadi "tidak ada aliran"). Pada akhirnya, perubahan status fungsi tersebut akan menggagalkan tujuan sistem obj2 untuk menyediakan aliran air ke sistem.

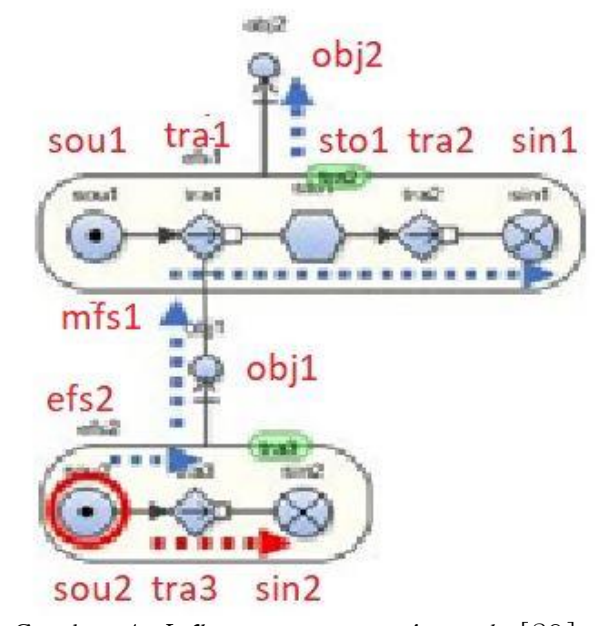

Gambar 4. Influence propagation rule [29].

\section{METODOLOGI}

Penelitian ini menggunakan diagram sistem pendingin primer RSG-GAS yang sudah disederhanakan, seperti terlihat pada Gambar 1. Komponen-komponen dalam diagram tersebut dipetakan dengan fungsi-fungsi dalam MFM untuk kemudian diubah menjadi model MFM. MFM digunakan dalam penelitian ini berdasarkan beberapa pertimbangan dan alas an. Pertama, MFM dibentuk berdasarkan hubungan sebab akibat [30] [8] sehingga sesuai dengan tujuan penelitian ini untuk menginvestigasi dampak dari suatu kejadian kegagalan. Kedua, jika dibandingkan dengan pemodelan berbasis objek lainnya, MFM menyediakan diagnosis komprehensif berbasis perspektif manusia tentang tujuan dari sistem [11]. Pada model lain, operator tidak dapat mengetahui proses diagnosisnya karena model tersebut hanya fokus pada hasilnya [31]. Terkait dengan penelitian ini, hal ini akan membantu dalam memahami fungsionalitas dari sistem pendingin primer RSG-GAS. Walaupun mempunyai beberapa kelebihan, MFM juga mempunyai kelemahan yaitu tidak dapat digunakan untuk analisis kuantitatif.

Beberapa kejadian kecelakaan terkait kehilangan aliran pendingin primer diterapkan pada model MFM tersebut. Kedua kejadian kecelakaan tersebut dipilih karena merupakan kecelakaan dasar desain seperti yang disebutkan dalam BAB XVI dari LAK RSG-GAS [15], dan merupakan potensi kecelakaan akibat dari kegagalan komponen utama sistem pendingin primer RSG-GAS yaitu katup isolasi, pompa primer dan alat penukar panas, seperti yang dijelaskan dalam referensi [32]. Selain itu kejadian kecelakaan LOFA pada RSG-GAS juga banyak dibahas pada beberapa literatur sehingga akan memudahkan dalam verifikasi hasil investigasi dalam penelitian ini.

MFM merupakan metode analisis yang bersifat kualitatif sehingga dalam analisis kejadian pada model MFM dari sistem pendingin primer RSG-GAS tidak mempertimbangkan nilai kuantitatif. Analisis kejadian kecelakaan dilakukan dengan menggunakan status fungsi MFM seperti yang disediakan pada Tabel 1. Dalam model MFM, penerapan kejadian kecelakaan karena adanya kegagalan fungsi pada suatu komponen berarti terdapat perubahan status pada fungsi tersebut. Perubahan status tersebut juga akan mempengaruhi status fungsi lainnya. Dampak dari perubahan ini dapat diinvestigasi menggunakan influence propagation rule. Hasll investigasi berupa fungsi-fungsi yang terdampak dikumpulkan dan dipetakan dengan komponen fisik dari sistem pendingin primer RSG-GAS. Terkait dengan manajemen penuaan, komponen-komponen tersebut harus mendapatkan perhatian, dan jika mengalami penuaan, harus segera dilakukan pemeliharaan atau penggantian untuk menghindari kegagalan fungsi dan menjamin reaktor beroperasi secara aman dan selamat.

\section{HASIL DAN PEMBAHASAN}

\subsection{Model MFM dari Sistem Pendingin Primer}

Model MFM dari sistem pendingin primer RSG-GAS terlihat pada Gambar 5. Model MFM tersebut dibuat mengikuti prosedur pembuatan 


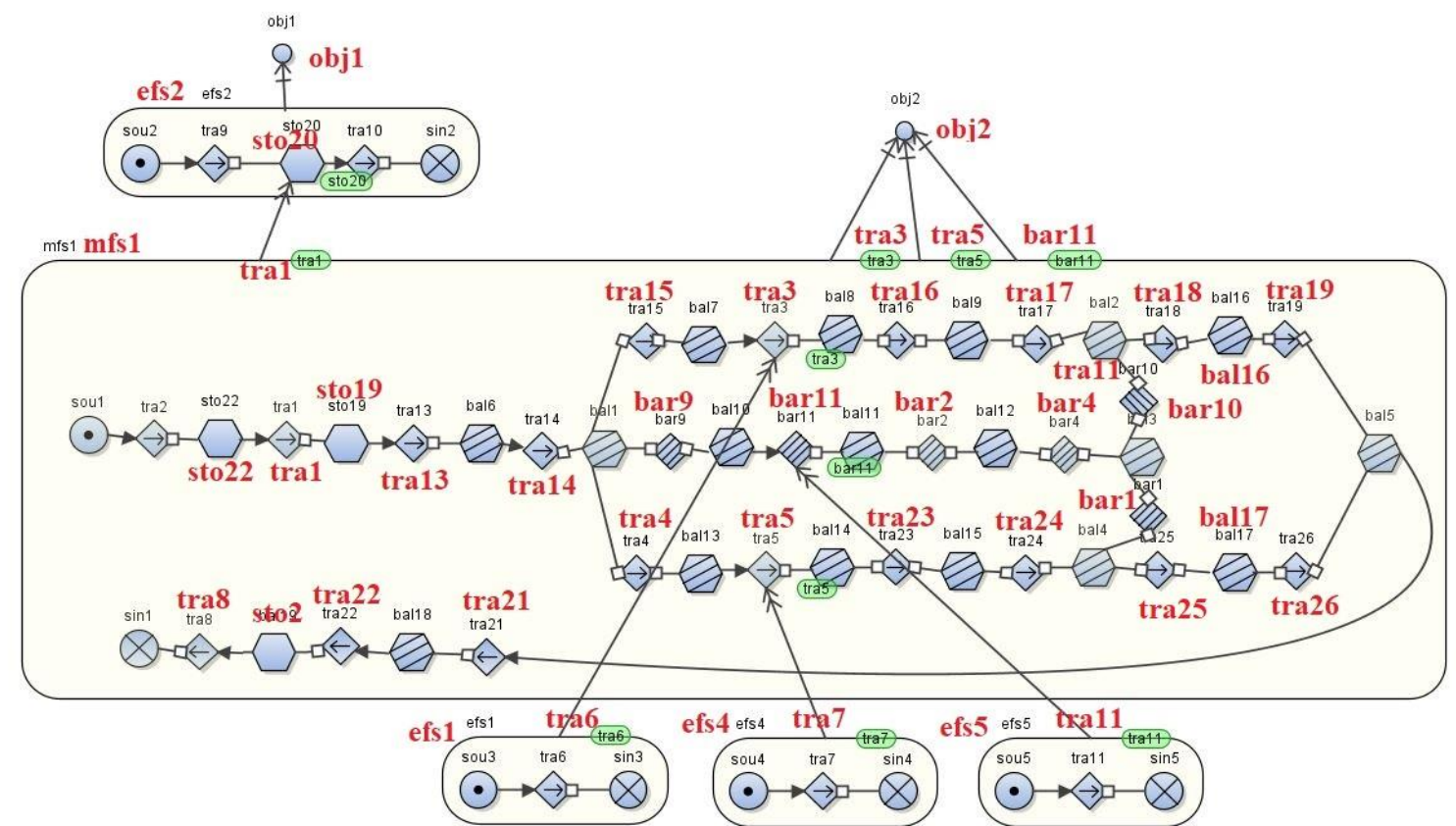

Gambar 5. Model MFM dari sistem pendingin primer RSG-GAS.

Tabel 2. Fungsi dalam MFM dan keseteraannya dengan komponen sistem pendingin primer

\begin{tabular}{llll}
\hline Simbol MFM & Komponen fisik & Simbol MFM & Komponen fisik \\
\hline sto22 & Teras reaktor & bar4 & JE01AA11 (katup) \\
sto19 & Delay chamber & tra24 & JE01AA09 (katup) \\
tra13 & JE01AA01 (katup) & tra18 & JE01AA14 (katup) \\
tra14 & JE01AA02 (katup) & bal16 & JE01BC01 (heat exchanger) \\
tra15 & JE01AA03 (katup) & tra19 & JE01AA16 (katup) \\
bar9 & JE01AA05 (katup) & bal17 & JE01BC02 (heat exchanger) \\
tra4 & JE01AA04 (katup) & tra26 & JE01AA17 (katup) \\
tra3 & JE01AP01 (pompa) & tra21 & JE01AA18 (katup) \\
bar11 & JE01AP03 (pompa) & tra22 & JE01AA19 (katup) \\
tra5 & JE01AP02 (pompa) & sto2 & Kolam reaktor \\
tra16 & JE01AA06 (katup) & & \\
bar2 & JE01AA10 (katup) & obj1 & Menghasilkan panas \\
tra23 & JE01AA08 (katup) & obj2 & Mendinginkan sistem \\
tra17 & JE01AA07 (katup) & & \\
\hline
\end{tabular}

model MFM seperti yang disebutkan dalam literatur [33]. Model MFM tersebut dibuat menggunakan perangkat lunak MFM Suite yang dikembangkan oleh Thunem dkk [34], [35]. Model MFM tersebut terdiri atas aliran massa (mfs1) yang merepresentasikan aliran pendingin pada sistem pendingin primer RSGGAS. Pompa-pompa primer selain direpresentasikan dalam aliran massa, juga ditampilkan sebagai aliran energi (efs1, efs4, dan efs5) yaitu aliran daya yang menghidupkan pompa tersebut. Tujuan dari sistem pendingin primer ditunjukkan oleh obj2 yaitu memberikan pendingin ke teras reaktor. Tabel 2 menunjukkan deskripsi dari masing-masing fungsi dalam model MFM tersebut dan kesetaraannya dengan komponen fisik sistem pendingin RSG-GAS. Sistem pendingin RSG-
GAS mempunyai 3 pompa primer redundan, 2 pompa dalam keadaan beroperasi dan 1 pompa dalam keadaan standby dan akan beroperasi jika salah satu pompa yang beroperasi mengalami kegagalan. Dalam model MFM pada Gambar 5 dan deskripsi pada Tabel 2, pompa yang beroperasi disimbolkan dengan fungsi transport (tra3 dan tra5) karena mengalirkan aliran pendingin, sedangkan untuk pompa standby karena tidak mengalirkan aliran pendingin maka disimbolkan dengan fungsi barrier (bar11). Hal ini juga berlaku untuk katup-katup yang terhubung dengan ketiga pompa primer tersebut. Jika terhubung dengan pompa yang beroperasi maka disimbolkan dengan fungsi tra, dan disimbolkan sebagai fungsi bar jika terhubung dengan pompa standby. 


\subsection{Skenario Kejadian Kecelakaan}

5.2.1 Berkurangnya aliran pendingin karena kegagalan prompa primer

Kejadian ini merupakan salah satu dari kejadian Loss of flow accident (LOFA) adalah kecelakaan akibat dari kehilangan pendingin. Hal ini dapat terjadi jika dua pompa primer yang bekerja secara paralel mengalami kegagalan fungsi akibat dari tidak adanya daya listrik atau karena sebab lain. Hal ini akan berakibat berkurangnya laju air pendingin dan menyebabkan reaktor menjadi trip atau shutdown. Dalam hal ini panas peluruhan dapat didinginkan menggunakan aliran pendingin yang berasal dari gaya inersia pompa yang akan mencapai nilai 0 menurut fungsi waktu [15]. Pada model MFM, kejadian LOFA ini dapat digambarkan seperti terlihat pada Gambar 6 . Pompa primer dimodelkan dengan tra3 dan tra 5 (beroperasi normal) dan bar 11 (dalam keadaan standby). Pada kondisi LOFA (berkurangnya aliran pendingin karena kegagalan pompa primer), status tra3 dan tra5 yang dtandai dengan lingkaran biru pada Gambar 6, berubah dari "normal” menjadi "aliran rendah" (karena ada gaya inersia pompa) dan akhirnya menjadi "tidak ada aliran" setelah beberapa saat.

Seperti dijelaskan pada bagian sebelumnya bahwa analisis yang dilakukan menggunakan MFM adalah bersifat kualitatiif sehingga tidak memperhitungkan nilai kuantitatif yang terkait dengan nilai penurunan laju aliran akibat kegagalan komponen dan juga waktu yang diperlukan oleh gaya inersia pompa dalam mengalirkan aliran pendingin setelah pompa mengalami kegagalan. Dengan demikian, investigasi dampak kegagalan tersebut dilakukan dengan menerapkan influence propagation yang menyatakan bahwa perubahan status pada suatu fungsi atau komponen akan memberikan dampak pada komponen yang terhubung dengan komponen tersebut. Aliran perubahan status dari komponen ditunjukkan dengan anak panah putus-putus berwarna biru.

Seperti terlihat pada Gambar 6, komponen yang terdampak akibat dari perubahan status dari tra3 (pompa primer), sebagai contoh adalah tra16 (katup JE01AA06) dan bal16 (alat penukar panas), Tabel 3 menunjukkan hasil dari investigasi komponen yang terdampak pada perubahan status tersebut. Tulisan berwarna merah menunjukkan komponen yang mengalami perubahan status (kegagalan fungsi).

Dari Tabel 3 terlihat bahwa jika pompa primer 1 (JE01AP01) mengalami kegagalan, walaupun tidak ada aliran daya listrik, motor pompa masih tetap berputar karena adanya gaya inersia yang akan mengirimkan aliran pendingin dengan laju rendah (aliran rendah). Hal ini akan mempengaruhi aliran pendingin ke katup-katup yang ditandai dengan status aliran rendah.

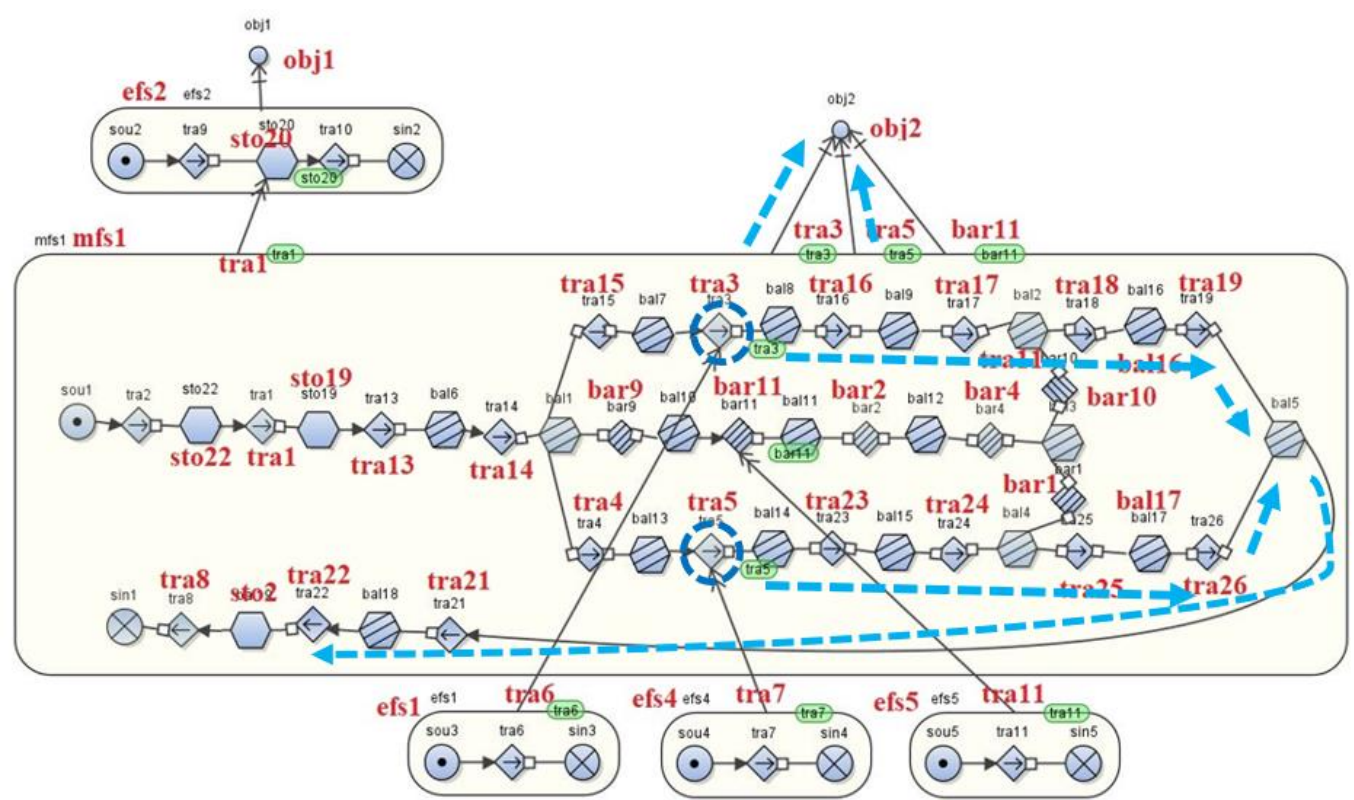

Gambar 6. Berkurangnya aliran pendingin karena kegagalan pompa primer. 
Tabel 3. Perubahan status fungsi MFM akibat dari kegagalan pompa pendingin

\begin{tabular}{llll}
\hline Fungsi MFM & Komponen & Status awal & Status akhir \\
\hline tra3 & JE01AP01 & Normal & Aliran rendah \\
tra16 & JE01AA06 & Normal & Aliran rendah \\
tra17 & JE01AA07 & Normal & Aliran rendah \\
tra18 & JE01AA14 & Normal & Aliran rendah \\
bal16 & JE01BC01 & Seimbang & Tak seimbang \\
tra19 & JE01AA16 & Normal & Aliran rendah \\
tra5 & JE01AP03 & Normal & Aliran rendah \\
tra23 & JE01AA06 & Normal & Aliran rendah \\
tra24 & JE01AA09 & Normal & Aliran rendah \\
tra25 & JE01AA15 & Normal & Aliran rendah \\
bal17 & JE01BC02 & Seimbang & Tak seimbang \\
tra26 & JE01AA17 & Normal & Aliran rendah \\
tra21 & JE01AA18 & Normal & Aliran rendah \\
tra22 & JE01AA19 & Normal & Aliran rendah \\
sto2 & Kolam reaktor & Normal & normal \\
obj2 & Tujuan mendinginkan sistem & Tercapai & tidak \\
\hline
\end{tabular}

Selain itu laju aliran pendingin yang rendah ini juga akan mempengaruhi kinerja penukar panas JE01BC01 dan JE01BC02 yang statusnya berubah menjadi tidak seimbang (unbalance). Dengan demikian pada saat kejadian ini terjadi, operator selain memantau pompa primer yang mengalami kegagalan, mereka juga harus memantau status katupkatup dan penukar panas. Dari Tabel 3 terlihat bahwa selain beberapa komponen yang mengalami dampak akibat kejadian tersebut, tujuan dari sistem obj2 untuk mendinginkan reaktor juga akan terganggu.

\subsubsection{Penutupan katup pompa primer dan alat} penukar panas

Kasus kedua yang diamati adalah penutupan katup pompa primer dan alat penukar panas. Pada saat reaktor beroperasi

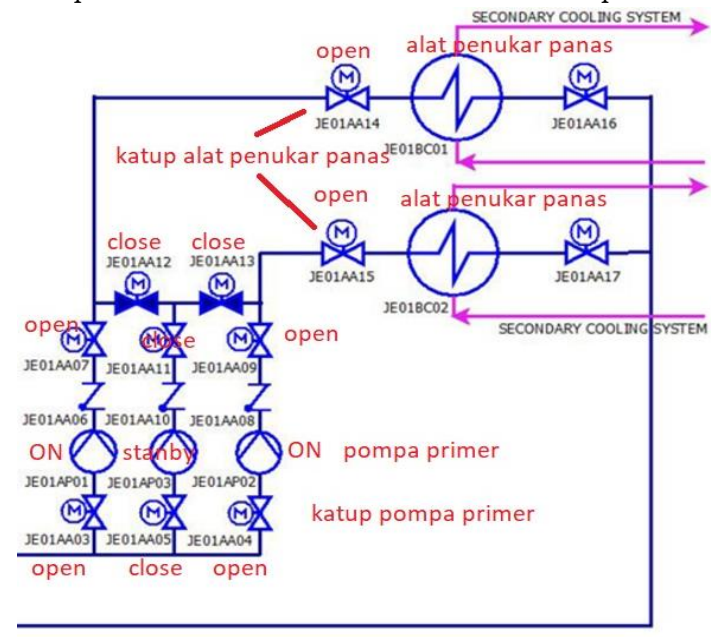

a normal, katup-katup tersebut berada dalam keadaan terbuka sehingga bisa mengalirkan aliran pendingin dari teras reaktor ke alat penukar panas, seperti terlihat pada Gambar 7.a. Sedangkan pada kejadian ini, seperti terlihat pada Gambar 7.b, katup-katup pompa prmer dan alat penukar panas yang digerakkan oleh motor tersebut tertutup secara tiba-tiba dan tidak sengaja.

Menurut LAK RSG-GAS BAB XVI [15], kejadian ini sedapat mungkin harus dihindari pada saat reaktor beroperasi karena akan menurunkan laju aliran pendingin sebanyak $2 / 3$ dari aliran normal. Gambar 8 menunjukkan implementasi kejadian tersebut pada model MFM. Katup-katup yang mengalami kegagalan tersebut adalah tra15 dan tra18 yang ditandai dengan lingkaran merah. Sedangkan efek dari kegagalan katup-katup ini ditandai dengan tanda anak panah putus-putus berwarna biru.

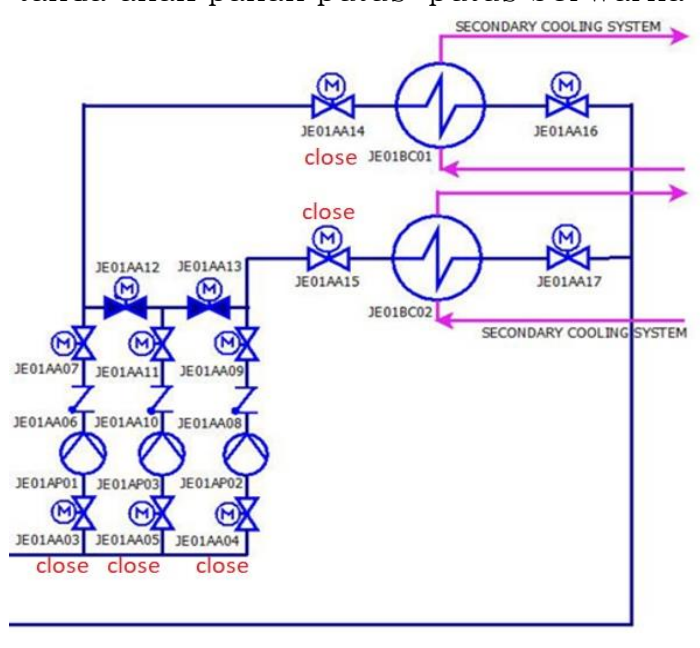

Gambar 7. Penutupan katup primer dan alat penukar panas. 


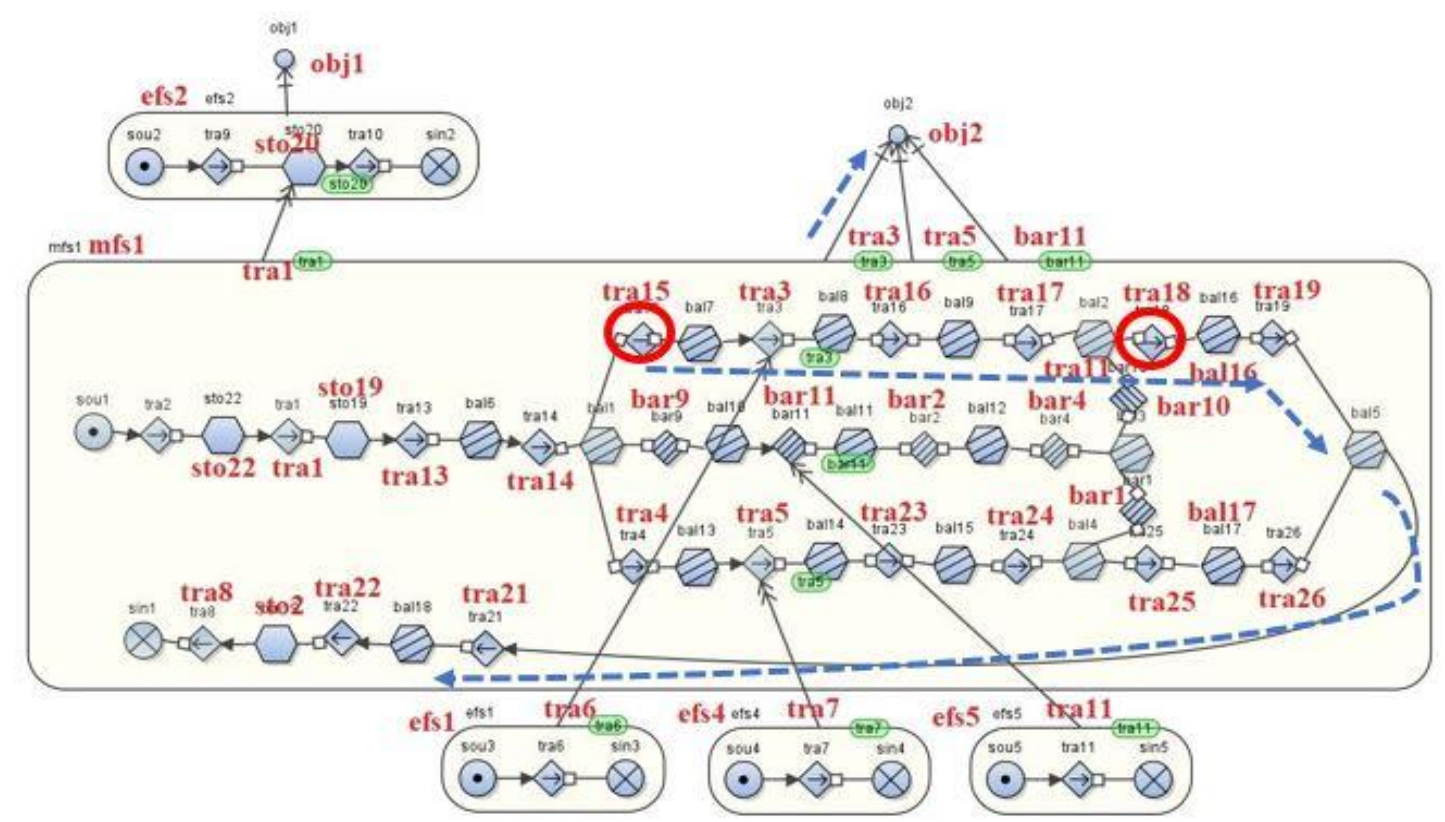

Gambar 8. Kehilangan air pendingin akibat kegagalan katup pompa primer dan penukar panas.

Tabel 4. Perubahan status fungsi MFM akibat dari penutupan katup pompa primer dan alat penukar panas

\begin{tabular}{llll}
\hline \multicolumn{1}{c}{ Fungsi MFM } & Komponen fisik & Status awal & Status akhir \\
\hline tra15 & Katup pompa primer (JE01AA14) & Normal & Tidak ada aliran \\
tra3 & Pompa primer (JE01AP01) & Normal & Tidak ada aliran \\
tra16 & Katup (JE01AA06) & Normal & tidak ada aliran \\
tra17 & Katup (JE01AA07) & Normal & Tidak ada aliran \\
tra18 & Katup (JE01AA14) & Normal & Tidak ada aliran \\
bal16 & Penukar panas (JE01BC01) & Normal & Tidak ada aliran \\
tra19 & Katup (JE01AA18) & Normal & tidak ada aliran \\
tra21 & Katup (JE01AA19) & Normal & Tidak ada aliran \\
tra22 & Inlet ke kolam reaktor & Normal & Tidak ada aliran \\
\hline
\end{tabular}

Tabel 5. Hasil investigasi dengan influence propagation rule

\begin{tabular}{lll}
\hline Kejadian & Sebab & \multicolumn{1}{c}{ Dampak } \\
\hline LOFA & Pompa primer (JE01AP01 dan JE01AP03) & - Katup JE01AA06, JE01AA07, JE01AA14, \\
& & JE01AA16, JE01AA18, JE01AA19 \\
& - Inlet kolam reaktor \\
\multirow{2}{*}{ LOFA } & Katup primer tertutup (JE01AA14) dan & - Penukar panas (JE01BC01) \\
& kegagalan penukar panas (JE01BC01) & - Katup (JE01AA16, JE01AA18, JE01AA19 \\
\hline
\end{tabular}

Hasil investigasi menggunakan influence propagation rule disajikan pada Tabel 4 . Dari Tabel 4 terlihat bahwa pada saat katup pompa primer JE01AA14 menutup secara tidak sengaja, ini akan berakibat tidak adanya aliran pendingin melewati katup tersebut dan juga ke pompa primer JE01AP0.

Hal ini jika terus berlangsung maka pompa akan mati yang berakibat reaktor menjadi scram. Walaupun pompa mempunyai gaya inersia, tidak ada aliran pendingin yang dialirkan karena tertutupnya katup tersebut. Jika kejadian ini juga diikuti oleh menutupnya katup pada alat penukar panas maka tidak ada aliran pendingin yang melewati alat penukar panas tersebut dan juga yang akan dialirkan ke kolam reaktor.

\subsubsection{Komponen-komponen terdampak}

Berdasarkan investigasi dari kejadian yang diimplementasikan pada model MFM tersebut maka diperoleh informasi yang terkait dengan dampak dari perubahan status komponen akibat dari suatu kejadian pada komponen lain dan sistem secara keseluruhan, seperti terlihat pada Tabel 5. Dari Tabel 5 terlihat bahwa komponen-komponen yang terdampak pada kejadian kegagalan pompa primer adalah katup penukar panas, penukar 
panas, dan katup pada inlet kolam reaktor. Sedangkan pada kasus katup primer dan alat penukar panas tertutup, komponen-komponen yang terdampak adalah katup output alat penukar panas, dan katup inlet kolam reaktor. Jika dibandingkan antara kedua kejadian tersebut, maka kegagalan pompa primer memiliki dampak yang lebih besar pada sistem pendingin primer tersebut karena lebih banyak komponen yang terdampak. Dengan demikian komponen kritis hasil dari investigasi ini adalah katup keluaran pompa primer, katup isolasi alat penukar panas, alat penukar panas, dan katup inlet kolam reaktor. Hasil ini jika dibandingkan dengan penelitian yang lain dalam hal ini yang telah dilakukan oleh [14] mendapatkan irisan yang sama tentang komponen kritis hasil dari investigasi yaitu katup-katup pada inlet kolam reaktor.

\section{KESIMPULAN}

Model MFM yang digunakan dalam penelitian ini mampu untuk melakukan analisis kejadian kecelakaan pada sistem pendingin RSG-GAS. Kejadian kecelakaan tersebut terkait dengan LOFA yaitu "berkurangnya aliran pendingin karena kegagalan pompa primer" dan "penutupan katup pompa primer dan alat penukar panas". Hasil investigasi menunjukkan bahwa komponen-komponen yang terdampak akibat dari kejadian tersebut adalah pompa primer, alat penukar panas, dan katup yang terhubung dengan kolam reaktor dapat dikelompokkan sebagai komponen penting dalam sistem pendingin primer. Hasil dari analisis tersebut juga berguna untuk membantu dalam penapisan komponen kritis sebagai salah satu kegiatan dalam manajemen penuaan RSG-GAS.

\section{SARAN/ REKOMENDASI}

Tindak lanjut dari penelitian ini adalah membuat model MFM dari sistem RSG-GAS secara keseluruhan dan menggunakan skenario kejadian kecelakaan yang lebih banyak. Selain mendapatkan komponen-komponen penting terkait program manajemen penuaan, informasi yang didapatkan tersebut dapat ditambahkan ke dalam antar muka prosedur berbasis komputer sebagai informasi tambahan untuk operator tentang dampak dari tindakan mereka setelah melakukan kendali mengikuti langkah-langkah dari prosedur tersebut.

\section{UCAPAN TERIMA KASIH}

Penulis mengucapkan terima kasih kepada Prof Akio Gofuku dari Okayama University atas bimbingan dan arahannya selama ini dalam melakukan penelitian terkait dengan MFM. Penulis juga mengucapkan terima kasih kepada Ir. Endiah Puji Hastuti sebagai ketua KAK Penilaian Keselamatan Reaktor. Penelitian ini dibiayai menggunakan DIPAPTKRN tahun anggaran 2020.

\section{DAFTAR ACUAN}

[1] J. E. N. McLeod and S. S. Rivera, "Human error hotspots in nuclear power plants," in Proc. World Congr. Eng. 2011, WCE 2011, vol. 1, no. July 2011, pp. 890-894, 2011.

[2] J. E. Núñez, M. Leod, and S. S. Rivera, "Human Error Management Optimization in CAREM NPP," Lect. Notes Eng. Comput. Sci., vol. 2176, no. 1, pp. 618622, 2009.

[3] P. H. Seong, H. G. Kang, M. G. Na, J. H. Kim, G. Heo, and Y. Jung, "Advanced MMIS toward Substantial Reduction in Human Errors in NPPs," Nucl. Eng. Technol., vol. 45, no. 2, pp. 125-140, 2013, doi: 10.5516/NET.04.2013.700.

[4] J. Rajzrova and J. Jirickova, "Severe accidents management in PWRs," in Proc. 2014 15th Int. Sci. Conf. Electr. Power Eng. EPE 2014, vol. 69, pp. 721-725, 2014, doi: 10.1109/EPE.2014.6839487.

[5] W. C. Cho and T. H. Ahn, "A classification of electrical component failures and their human error types in South Korean NPPs during last 10 years," Nucl. Eng. Technol., vol. 51, no. 3, pp. 709-718, 2019, doi: 10.1016/j.net.2018.12.011.

[6] BAPETEN, Perka Bapeten no 54: Ketentuan Keselamatan Manajemen Penuaan Reaktor NonDaya. Badan Pengawas Tenaga Nuklir, Jakarta, 2008.

[7] Peraturan Presiden No. 54: Keselamatan dan Keamanan Instalasi Nuklir. Jakarta. 2012.

[8] M. Lind, "An introduction to multilevel flow modeling," Nucl. Saf. Simul., vol. 2, no. 1, pp. 2232, 2011.

[9] X. Zhang, M. Lind, and O. Ravn, "Consequence reasoning in multilevel flow modelling," in IFAC Proc. Vol., vol. 12, no. PART 1, pp. 187-194, 2013, doi: 10.3182/20130811-5-US-2037.00028.

[10] J. Wu, M. Lind, X. Zhang, and P. Karnati, "Barrier Identification by Functional Modeling of a Nuclear Power System," in Proceedings of ISOFIC 2017, pp. 1-10, 2017.

[11] T. J. Suryono and A. Gofuku, "Techniques to derive 
additional information of operation actions for computer-based operating procedure," J. Nucl. Sci. Technol., vol. 55, no. 6, pp. 672-683, 2018, doi: 10.1080/00223131.2018.1428122.

[12] W. E. I. Qin and P. H. Seong, "A Validation Method For Emergency Operating Procedures Of Nuclear Power Plants Based On Dynamic Multi-Level Flow Modeling," Nucl. Energy Technol., vol. 37, no. 1, pp. 118-126, 2005.

[13] M. Song and A. Gofuku, "Planning of Alternative Countermeasures for a Station Blackout at a BWR Using Multilevel Flow Modeling," Nucl. Eng. Technol., vol. 50, no. 4, pp. 542-552, 2018, doi: 10.1016/j.net.2018.03.004.

[14] Deswandri, M. Subekti, and G. R. Sunaryo, "Reliability Analysis of RSG-GAS Primary Cooling System to Support Aging Management Program," J. Phys. Conf. Ser., vol. 962, no. 1, 2018, doi: 10.1088/1742-6596/962/1/012002.

[15] PRSG, "Laporan Analisis Keselamatan RSG-GAS: BAB XVI Analisis Keselamatan". PRSG-BATAN. Serpong, 2011.

[16] M. Lind, "Control functions in MFM: basic principles," Nucl. Saf. Simul., vol. 2, no. 2, pp. 132129, 2011.

[17] J. Larsson and F. Dahlstrand, "Reliability Analysis Based on Multilevel Flow Models," 2002, [Online]. Available:

http://www.goalart.com/publications/2002-

Maryland.pdf.[Accessed: 01 Agustus 2020]

[18] M. Lind and X. Zhang, "Functional Modelling for Fault Diagnosis and its Applications for NPP," Nucl. Eng. Technol., vol. 46, no. 6, pp. 753-772, 2014, doi: 10.5516/NET.04.2014.721.

[19] G. Akio, "Support systems of plant operators and designers by function-based inference techniques based on MFM models," Int. J. Nucl. Saf. Simul., vol. 2, no. 4, pp. 327-338, 2011.

[20] G. Akio and O. Ai. 2010. A systematic fault tree analysis based on multi-level flow modeling. (eds) Progress of Nuclear Safety for Symbiosis and Sustainability. Tokyo: Springer, 2010.

[21] A. Gofuku and T. Sato, "Dynamic operation permission system for oil refinery plants," in Proc. 2009 IEEE Int. Conf. Networking, Sens. Control. ICNSC 2009, vol. 14, no. 2, pp. 746-751, 2009, doi: 10.1109/ICNSC.2009.4919371.

[22] K. Heussen, A. Saleem, and M. Lind, "Control architecture of power systems: Modeling of purpose and function," in 2009 IEEE Power Energy Soc. Gen. Meet. PES '09, no. August, 2009, doi: 10.1109/PES.2009.5275963.

[23] M. Lind and X. Zhang, "Functional modelling for fault diagnosis and its application for NPP," Nucl. Eng. Technol., vol. 46, no. 6, pp. 753-772, 2014, doi: 10.5516/NET.04.2014.721.

[24] A. Gofuku, T. Inoue, and T. Sugihara, "A technique to generate plausible counter-operation procedures for an emergency situation based on a model expressing functions of components," Nucl. Sci. Technol., vol. 54, no. 5, pp. 578-588, 2017, doi: 10.1080/00223131.2017.1292966

[25] M. Lind, H. Yoshikawa, S. B. Jørgensen, Y. Ming, K. Tamayama, and K. Okusa, "Multilevel flow modeling of monju nuclear power plant," Nucl. Saf. Simul., vol. 2, no. 3, pp. 274-284, 2011.

[26] J. Wu, L. Zhang, S. B. Jørgensen, N. Jensen, X.
Zhang, and M. Lind. August 2014. "Procedure for validation of a functional model of a central heating system. Presented at World Conf. Saf. Oil Gas Ind., [Online].Available:https://www.researchgate.net/p rofile/Jing_Wu40/publication/264552162_Procedur e_for_validation_of_a_functional_model_of_a_centr al_heating_system/links/53e575250cf2fb74871824 Oc.pdf.[Accessed: 07 August 2020]

[27] E. K. Nielsen, A. Gofuku, X. Zhang, O. Ravn, and M. Lind, "Causality validation of multilevel flow modelling," Comput. Chem. Eng., vol. 140, 2020, doi: 10.1016/j.compchemeng.2020.106944.

[28] E. K. Nielsen, M. V. Bram, J. Frutiger, G. Sin, and M. Lind, "A water treatment case study for quantifying model performance with multilevel flow modeling," Nucl. Eng. Technol., vol. 50, pp. 532541, 2018, doi: 10.1016/j.net.2018.02.006.

[29] A. Gofuku, S. Koide, and N. Shimada, "Fault Tree Analysis and Failure Mode Effects Analysis Based on Multi-level Flow Modeling and Causality Estimation," 2006 SICE-ICASE Int. Jt. Conf., pp. 497-500, 2006, doi: 10.1109/SICE.2006.315478.

[30] X. Zhang and M. Lind, "Reasoning about Causeeffect through Control Functions in Multilevel Flow Modelling," in Proceeding of International Symposium on Future Instrumentation and Control for Nuclear Power Plants, Gyeongju, 2017.

[31] Y. Zhou, H. Yoshikawa, W. Wu, M. Yang, and H. Ishii, "Modeling Goals and Functions of Micro Gas Turbine System by Multilevel Flow Models," Inf Media Tech, vol. 1, pp. 963-972, 2006.

[32] A. Abtokhi dan J. Situmorang, "Evaluasi Keandalan Menggunakan Petri Net pada Kejadian Kehilangan Aliran Pendingin Reaktor Riset RSG-GAS”, in Prosiding Seminar Nasional ke-19 Teknologi dan Keselamatan PLTN Serta Fasilitas Nuklir, Yogyakarta, 2013.

[33] Wu, Jing, "Functional Modeling Methodology of Complex System and Its Application in Safety Assessment", Dissertation submitted to China University of Petroleum, Beijing, May, 2016, doi: 10.13140/2.1.3250.0809.

[34] H. P. J. Thunem. 2017. "An Overview of the MFM Suite for Diagnostic and Prognostic Reasoning of Industrial Process Plants,”. [Online].Available: http://hdl.handle.net/11250/2557964. [Accessed: 08 August 2020].

[35] H. P. Thunem. "The continued development of the MFM suite and its practical application on a PWR system". in European Safety and Reliability Conference, Zurich, pp. 2463-2471, 2015. 
HALAMAN INI SENGAJA DIKOSONGKAN 